\section{Dirachma socotrana}

I am writing in connection with the article, Dirachma socotrana - back from the brink? (Bazara'a, Guarino, Obadi and Miller, 1991, Oryx $, 25,229-232)$. I am afraid that the authors have been misled concerning the vernacular name of this species. Dr Georg August Schweinfurth, besides being an outstanding botanist and extensive traveller, was also an accomplished Arabist, and lived for many years in Cairo. I would, therefore, be inclined to think twice about calling into question any information he gleaned on the subject of plant names in the Arab world and surrounding regions. He recorded two variants for the vernacular name of this species, namely 'Dirachma' and 'Rachman'.

However, there were on our 1967 expedition to Socotra two linguists, the late Dr Tom Johnstone of the School of Oriental and African Studies, University of London, and $\mathrm{Mr}$ Mike Tomkinson, at that time of the British Embassy in Jeddah, Saudi Arabia, and a Fellow of the Institute of Linguistics, as well as Mr J. J. Lavranos, an extensive traveller in Arab lands and also a fluent Arabic speaker. All of these three, independently, recorded names for the species that differed in no significant respect from the names recorded by Schweinfurth 86 years previously. These were: 'Dirahmim' (Lavranos, myself being present); 'Di-rahmim' (Johnstone, MS list) and 'di-rahmim' (Tomkinson, TS list). Q. Cronk in 1985, moreover, recorded the name 'Drahman', which is again similar.

None of us ever recorded this name for Cephalocroton socotranus (not socotrana, as in the paper, because Croton is masculine), which, as the paper states, is the 'tahn'. This latter is the only name, or slight variants of it, for the Cephalocroton, which, as far as my observations went, was never cut for timber (it is only a shrub anyway, and not a tree, as stated in the paper, and therefore its wood is not very substantial). The variants are: 'tehn' (Balfour, Cockburn and Scott); 'than'

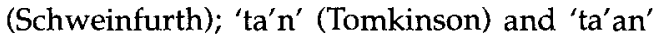
or 'tann' (Cronk).

The authors of the paper, unfortunately per- petrated another error by ascribing the name 'tifit' to the Dirachma, thus obfuscating the issue still further! This is clearly a variant spelling of the 'Difeth', which is the name Schweinfurth recorded for Placopoda virgata Balf.f., an endemic rubiaceous genus on Socotra, since Lavranos and I recorded another and similar variant for this species, namely 'taifet', on two separate occasions. This shrub is rather rare and, as the specific epithet implies, only produces slender twigs; it is not therefore of any commercial value.

A. Radcliffe-Smith, Royal Botanic Gardens Kew, Richmond, Surrey TW9 3AB, UK.

\section{To collect or not - continued}

It is surprising to find Sir Christopher Lever (Oryx, 26, 173-174) falling back on one of the oldest devices of those running out of facts in an argument. In the past it was usual in a religious controversy to suggest that the other side was somehow lacking in 'Faith', which immediately discredited them. In the modern equivalent it has become usual for one side to accuse the other of lacking 'understanding'.

Surely with universal television, such accusations of incomprehension have become as obsolete as Bishop Wilberforce's attack on Darwin? Nearly everyone 'understands' conservation issues these days; the problem is that some do not agree with the solutions proposed, and they will not be converted by accusations of a lack of 'understanding'.

In point of fact, taxonomists have often been only too eager to adopt new techniques, sometimes before they were adequately investigated, and pictures in particular have been treated as acceptable types since the start of taxonomy. But now that it is being realized that in many groups of organisms there are sibling species that are difficult to tell apart, it is increasingly necessary to have reliable types, and some of the characters cited by Sir Christopher such as genetic material are not so easily related to ordinary experience of normal organisms.

If Sir Christopher wishes to resort to science in support of arguments against collecting, 